\title{
Belle Fourche River-Cheyenne River Drainage Divide Area in the Wyoming Powder River Basin Analyzed by Topographic Map Interpretation Methods, USA
}

\author{
Eric Clausen ${ }^{1}$ \\ ${ }^{1}$ Independent Researcher, Jenkintown, PA (USA) 19046, USA \\ Correspondence: Eric Clausen, 100 West Ave D-17, Jenkintown, PA 19046 USA. E-mail: eric2clausen@gmail.com
}

Received: February 18, 2018

Accepted: February 28, 2018

Online Published: March 12, 2018

doi:10.5539/jgg.v10n2p1

URL: http://dx.doi.org/10.5539/jgg.v10n2p1

\begin{abstract}
The dearth of scientific literature in which specific erosional landform origins are determined is an example of what Thomas Kuhn considered a scientific crisis. Scientific crises arise when scientists following their discipline's established paradigm's rules, or doing what Kuhn calls normal science, cannot explain observed evidence. Scientific crises are resolved in one of three ways. Normal science may eventually explain the evidence and normal science returns, the unsolved problems may be identified and labeled and left for future scientists to solve, or a new paradigm may emerge with an ensuing battle over its acceptance. To succeed any new paradigm must demonstrate its ability to explain the previously unexplained evidence and also open up new research opportunities. During the $20^{\text {th }}$ century's first half regional geomorphologists abiding by their discipline's paradigm rules unsuccessfully tried to explain origins of numerous erosional landforms, such as drainage divides and erosional escarpments. Their failures eventually caused the regional geomorphology discipline, at least that part of the discipline concerned with determining specific erosional landform origins, to almost completely disappear. A new and fundamentally different geomorphology paradigm that requires massive southeast-oriented continental ice sheet melt-water floods to have flowed across the Powder River Basin has the ability to explain specific erosional landform origins and is demonstrated here by using detailed topographic map evidence to show how large southeast-oriented floods eroded the Powder River Basin's Belle Fourche River-Cheyenne River drainage divide segment, eroded through valleys now crossing that drainage divide segment, eroded the Powder River Basin's Belle Fourche River valley, established Belle Fourche and Cheyenne River Powder River Basin tributary valley orientations, and eroded the north-facing Pine Ridge Escarpment. The success of this and other similar new paradigm demonstrations suggest many if not all specific erosional landform origins can be determined.
\end{abstract}

Keywords: anomalous evidence, continental ice sheet melt water floods, erosional landform origins, new paradigm, Pine Ridge Escarpment, regional geomorphology, scientific crisis

\section{Introduction}

Pick just about any specific United States erosional landform, and next search the geography and geology literature for research papers in which that specific erosional landform's history is investigated. Except for well-known erosional landforms the literature search will probably discover, if it discovers anything at all, papers dating back to the first half of the last century or perhaps a few more recent publications with brief summaries of that earlier work. The simple fact is the research discipline of regional geomorphology, in which specific erosional landform histories are investigated, has almost disappeared. The almost complete absence of recent regional geomorphology literature could lead one to believe all specific erosional landform histories have been determined or are so obvious no further research is needed. Yet, for those well-known erosional landforms, such as the Grand Canyon, where recent research papers actually do exist, the origins of those specific erosional landforms are highly debated (e.g. Karlstrom et al, 2014).

The near disappearance of regional geomorphology literature during the mid 20th century was not because all regional geomorphology research questions had been answered. Instead it was because regional geomorphologists using their established paradigm rules could not explain erosional landform origins. For example Thornbury's 1965 book "Regional Geomorphology of the United States" reveals many unresolved 
erosional landform problems, yet following that book's publication little or no research has investigated many of those unsolved problems. Thomas Kuhn (1965) describes such situations in his book "The Structure of Scientific Revolutions" as scientific crises that develop because scientists doing normal science (following accepted discipline paradigm rules) cannot explain anomalous evidence. For the regional geomorphology research community erosional landforms origins became anomalous evidence (e.g. Strahler, 1945). According to Kuhn such crises are eventually resolved in one of three ways: normal science eventually explains the anomalous evidence and the established paradigm continues without serious interruption, the crisis persists and the unsolved problems are identified and labeled for future study (just as Thornbury's book did for a number of significant unsolved problems), or "the crisis may end with the emergence of a new candidate for paradigm and with the ensuing battle over its acceptance."

This paper demonstrates how a new geomorphology paradigm explains previously unexplained erosional landforms in the Powder River Basin's Belle Fourche River-Cheyenne River drainage divide area. The new paradigm requires continental ice sheet melt water floods to have eroded North America's entire Missouri River drainage basin (where the Powder River Basin and the Belle Fourche-Cheyenne River drainage divide are located). From the established paradigm's perspective such a requirement is impossible (e.g. how did continental ice sheet melt water flow over Rocky Mountain ranges?). That new paradigm requirement however forces recognition of an immense continental ice sheet created and occupied deep "hole". Creation of such a deep "hole" means ice sheet related crustal warping occurred while large melt water floods flowed from the ice sheet's margin across the deep "hole's" developing rim and then across rising mountain ranges and plateau areas, again impossible from the established paradigm's perspective. An ice sheet created and occupied deep "hole" also means southeast-oriented ice-marginal floods flowed at higher elevations than the deep "hole's" floor elevation. That elevation difference meant late during the ice sheet's melt history space at the deep "hole's" southern end opened up and deep valleys eroded headward from that space to capture the immense southeast-oriented ice-marginal melt water floods and to divert those ice-marginal melt water floods onto and across the newly exposed deep "hole's" floor.

The Wyoming Powder River Basin seen in figure 1 extends northward into southeast Montana and is located between the Bighorn Mountains and the Black Hills and is also located entirely within the Missouri River drainage basin. The Cheyenne River and its Belle Fourche River tributary both originate in the Powder River Basin and then completely encircle the Black Hills before joining as the Cheyenne River to flow in a northeast direction to join the south-oriented Missouri River. New paradigm rules predict the Cheyenne and Belle Fourche River valleys and their tributary valleys, including those in the high Black Hills, eroded headward during immense southeast-oriented continental ice sheet melt water floods. Supporting the new paradigm Clausen (2017a, 2017b, 2017c) presented evidence suggesting southeast-oriented floods of possible continental ice sheet melt water origin did flow across drainage divides to the east and the north of the Black Hills. Clausen (2018) also presented evidence that southeast-oriented floods flowed across the Spearfish-Rapid Creek drainage divide segment of the Belle Fourche-Cheyenne River drainage divide, which now crosses some of the Black Hills' highest regions. This paper seeks to determine whether or not the new paradigm also explains previously unexplained Powder River Basin erosional landform evidence and asks the question "did large southeast-oriented floods create the Powder River Basin segment of the Cheyenne and Belle Fourche River drainage divide and its associated features? "

\section{Previous Research}

The Powder River Basin is one of several large structural basins located between Rocky Mountain ranges. Love (1960) reports basin formation may have begun in latest Cretaceous time and had ended by Oligocene time meaning the Powder River Basin is primarily filled with Cenozoic non-marine sediments, although older and thinner Paleozoic and Mesozoic sediments underlie the thick and more easily eroded Cenozoic sediments. Geologic maps done by Ver Ploeg and Boyd, (2003), McLaughlin and Ver Ploeg (2006), and Gregory and Michale (2007) cover the Powder River Basin segment of the Belle Fourche River-Cheyenne River drainage divide studied here and show both rivers flow for considerable distances in areas underlain by the Tertiary Wasatch Formation before crossing narrower zones of the Tertiary Fort Union Formation's Tongue River, Lebo, and Tullock Members, and then the Cretaceous Lance Formation, Fox Hills Sandstone, and Pierre Shale as the Black Hills are approached.

Primary Powder River Basin references used here were detailed topographic maps available on the United States Geological Survey (USGS) National Map website. In addition to offering different map and imagery types at various scales the website offers the ability to add a number of cartographic layers and to use several GIS tools, although detailed digitalized topographic maps based on previously published hard copy maps provided all 
information required for this study. The USGS Topoview website provides access to the USGS Historical Topographic Map Collection from which USGS hard copy topographic map publication dates can be obtained. While some hard copy topographic maps of the Black Hills region with 50-foot (15-meter) contour intervals were published in the early 1900s, 1:250,000-scale topographic maps with 200-foot (61-meter) contour intervals for all Powder River Basin areas were first published during the 1950s. More detailed 1:24,000-scale maps covering selected Powder River Basin areas, usually offering a 20-foot (6-meter) contour interval, were first published beginning in the 1950s with many areas not covered until the 1980s. Many detailed topographic maps for Belle Fourche River-Cheyenne River drainage divide areas needed to do a study of the type reported here were first published in the early and mid 1980s. Interestingly regional geomorphology was disappearing as a research discipline before much Powder River topographic map coverage at any scale or with any contour interval was publicly available.

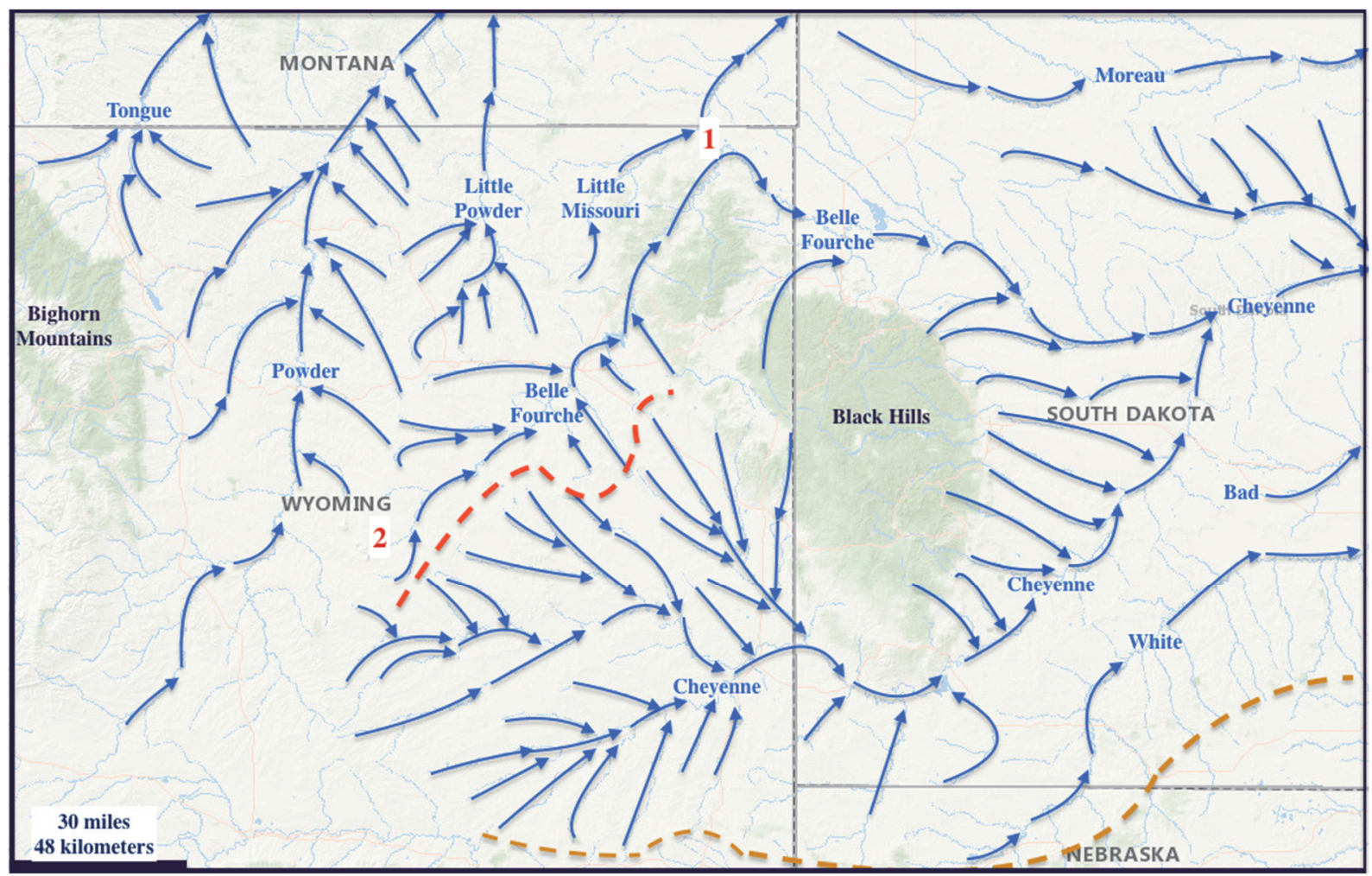

Figure 1. Modified map from the United States Geological Survey (USGS) National Map website showing the Powder River Basin location between the Bighorn Mountains and Black Hills in northeast Wyoming and river systems discussed in the text. The dashed red line shows the drainage divide segment studied here and the dashed brown line shows the Pine Ridge Escarpment and Hat Creek Breaks approximate locations

Published literature from any date describing Powder River Basin drainage history is sparse although a Belle Fourche River capture of its northeast-oriented Powder River Basin headwaters is frequently cited as a stream capture example. The Belle Fourche River originates near the Powder River Basin central area and flows in a northeast and north-northeast direction to the Black Hills northern tip where it turns in a southeast direction to flow along the Black Hills northeast flank. A short southeast-to-northwest oriented through valley (number 1 on figure 1) today links the northeast-oriented Little Missouri River valley with the Belle Fourche River abrupt turn. Darton (1909) suggested headward erosion of the southeast-oriented Belle Fourche River valley captured the northeast and north-northeast Belle Fourche River headwaters, which he said had previously flowed to the northeast-oriented Little Missouri River. Because water in the southeast-oriented Belle Fourche River valley segment flows for a much shorter distance to reach the central South Dakota south-oriented Missouri River than water in the northeast-oriented Little Missouri River valley, subsequent investigators (e.g. Zaprowski et al, 2001) to date have found no reason to question Darton's capture hypothesis. Stamm et al (2013) estimate this piracy occurred at about 22 to $21 \mathrm{ka}$.

The dashed brown line in figure 1 shows the Pine Ridge Escarpment location. In Wyoming the escarpment 
follows the Cheyenne River drainage basin southern margin and is known as the Hat Creek Breaks. The north-facing Pine Ridge Escarpment in Nebraska and South Dakota represents a rise of hundreds of feet (meters) from its base to higher plains at its rim and is one of the region's most prominent physiographic features. According to Fenneman (1931) the Pine Ridge Escarpment retreated in a southward direction by at least 200 miles (322 kilometers) and Meyerhoff and Olmstead (1937) associated the high plains surface (at the Pine Ridge Escarpment rim) with the higher elevation Black Hills sub-summit erosional surface. Thornbury (1965) considered the Pine Ridge Escarpment origin "uncertain; it apparently is not the product of a particular resistant formation; more likely it marks the boundary between two topographic levels of erosion in the Central Lowlands and the Great Plains." The White River originates on the high plains south of figure 1 and descends in a deep valley cut into the Pine Ridge Escarpment face before turning in a northeast direction to enter South Dakota. Deep erosion has removed hundreds of feet (meters) of sedimentary bedrock from between the Black Hills and the Pine Ridge Escarpment. Today the Cheyenne River is the only drainage route flowing between the Black Hills and the Pine Ridge Escarpment, although the northeast- and east-oriented White River drains the area just to the east. Multiple investigators (Todd, 1902, Wanless, 1923, Stamm et al, 2013, Clausen, 2017a, and others) have described how in the area to the east of the Black Hills headward erosion of the northeast-oriented Cheyenne River valley captured southeast-oriented streams that once flowed to the northeast- and east-oriented White River.

Oligocene rocks present at Pumpkin Buttes (number 2 on figure 1), which rise to more than 6000 feet (1845 meters) near the Powder River Basin center and on the Powder River-Belle Fourche River drainage divide, were used by Seeland (1985) to reconstruct the regional paleogeography. He reports, "The Oligocene Arctic Ocean-Gulf of Mexico continental divide extended ... across the southern Powder River Basin, through the northern Black Hills, and eastward across South Dakota. Streams north of the divide generally flowed northeastward. One... flowed through the Powder River Basin, and crossed the northernmost Black Hills, in a valley nearly coextensive with the valley of the Belle Fourche River and...[then] flowed through the Lake Winnipeg and Hudson Bay lowlands into the Labrador Sea off northeastern Canada." Seeland was by no means the first to make such a suggestion. Flint $(1949,1955)$, who worked primarily in eastern South Dakota, considered the Cheyenne River a pre-glacial north-oriented river. This hypothesized north-oriented pre-glacial drainage system is entrenched in today's geologic literature and is sometimes referred to as the Bell River system. Most recently Sears (2013) suggested that during late Oligocene and early Miocene time the Colorado River may have turned northward from the Arizona Grand Canyon area to flow into southwest Montana where it joined the pre-glacial north-oriented Bell River drainage system.

While they did not directly work in the Powder River Basin W.C. Alden and R.F. Flint contributed heavily to established paradigm landscape evolution ideas. Alden (1932) described eastern Montana physiographic and glacial history and during much of the first half of the $20^{\text {th }}$ century significantly influenced USGS geomorphology research directions. Alden and Flint both worked from the established paradigm perspective and helped to shape the established paradigm rules. In 1927, after a presentation in which J Harlan Bretz described evidence for catastrophic flood erosion of the Washington State Channel Scablands Alden commented that while he had not worked in the region he considered a flood explanation unnecessary (Bretz, 1927). Flint, who shaped many aspects of the North American glacial history paradigm actually worked in the Washington State Channeled Scablands and in one of his published papers (Flint, 1938) concludes, "the evidence submitted points to streams of normal discharge, which lowered their profiles through deposits that they themselves had built." Today few geomorphologists question Bretz's catastrophic flood interpretation. Baker (1981) has reproduced several previously published papers illustrating how the Channeled Scabland controversy evolved and also describing erosional landform features now considered to be catastrophic flood evidence. Among those landform features are anastomosing valley complexes formed when water spills over pre-existing drainage divides to flow as diverging and converging streams. Such anastomosing channel complexes have been used elsewhere to identify other catastrophic flood events. For example, Kehew (1981) interpreted one such complex near Minot, North Dakota, as having been eroded during Glacial Lake Regina's catastrophic failure.

A previously proposed new geomorphology paradigm, involving a continental ice sheet eroded deep "hole" (White, 1972, 1988), did not satisfactorily explain the Bell River system and sediments directly and indirectly associated with it. While White's deep erosion by continental ice sheets paradigm explained some evidence, like most newly introduced paradigms, it encountered resistance with some of the strongest resistance coming from Gravenor (1975), Sugden (1976), Higgs (1978), and Rutter (1980). White's critics argued among other things that glacially deposited debris in Bell River system valleys is evidence those valleys survived ice sheet erosion and mid and late Tertiary sediments in and near Belle River system river valleys were deposited prior to 
Pleistocene glaciations. According to Kuhn (1965) paradigms are neither correct nor incorrect, but succeed or fail based on their ability to explain previously unexplained evidence and to open up new research opportunities. While unstated by White's critics, the most serious problem White's proposed paradigm encountered was its inability to explain any more evidence than the established paradigm could explain, nor did White's paradigm open up new research opportunities.

\section{Research Method}

In 1980 the author became interested in coarse-grained igneous rock alluvium contained in southwest North Dakota Oligocene sediments and he traced distinctive rock types to source areas in the Montana Beartooth Mountains and other Montana mountain ranges. The trail suggested large volumes of water had flowed from what are now high Beartooth Mountain areas in a northeast direction to near the present day Montana-North Dakota border where at least some of the water had been deflected in an east and southeast direction along what is a well-recognized continental ice sheet margin. Vertebrate paleontologists usually treat the alluvium as anomalous evidence and in ensuing discussions insisted a pre-glacial north-oriented Little Missouri River had transported the alluvium in a northward direction from unidentified Black Hills source areas and along an unidentified trail. Realizing vertebrate paleontologists could not and would not explain the observed evidence the author finally decided to attack the problem by using previously unstudied and paradigm neutral detailed topographic map evidence. That decision ultimately led to the Missouri River drainage basin landform origins research project from which the new geomorphology paradigm was constructed.

The larger project consisted of systematically studying detailed United States Geologic Survey (USGS) topographic maps of the entire Missouri River drainage basin and adjacent drainage basins to determine how major drainage divides within and surrounding the Missouri River drainage basin originated. Drainage divide origins were determined by using divide crossings (through valleys, wind gaps, mountain passes, etc.) as evidence of previous drainage routes and then using barbed tributaries, elbows of capture, asymmetric drainage divides, abandoned headcuts, and similar evidence to determine how many thousands of capture events altered earlier drainage routes so as to produce the present day Missouri River drainage basin drainage routes. Preliminary work leading to the larger project was done during the 1980s and 1990s with the first Missouri River drainage basin landform origins research project being done from 1999 to 2001. Preliminary work and the first project used large mosaics of hard copy detailed topographic maps. To confirm first project results a second project was undertaken from 2011 to 2013 and used National Geographic TOPO software to again determine origins of all drainage divides within and surrounding the Missouri River drainage basin. All second project research notes pertaining to each studied drainage divide area were written as unpublished essays in blog format and are publicly available at geomorphologyresearch.com.

Selected project subcomponents are now being redone using United States Geological Survey (USGS) National Map website maps as new paradigm demonstrations such as the one presented here. The USGS National Map website provides GIS features not available when the project was initially done. Website features used while preparing this paper included the ability to easily view regions of interest using different types of topographic maps and imagery at various scales and the measuring and spot elevation tools. While other GIS features and tools are available, for purposes of determining erosional landform origins the use of simple topographic map interpretation techniques and digitalized topographic maps that provide the same types of information and detail as USGS hard copy 1:24,000 scale topographic maps were determined to be the best research method and material. Detailed topographic maps have low enough contour intervals to enable a skilled topographic map interpreter to visualize detailed landform shapes and such maps include enough drainage route names so visualized landforms can easily be described.

Research pertaining to this paper began by dividing the Powder River Basin segment of the Belle Fourche River-Cheyenne River drainage divide into shorter segments and then identifying remnants of former valleys now crossing those drainage divide segments. Those valley remnants were considered evidence of drainage routes that existed before Belle Fourche River-Cheyenne River drainage divide creation. The identified valley remnants were studied to determine whether or not they linked Belle Fourche River tributary valleys with Cheyenne River tributary valleys. Lengths and orientations of tributaries and river valley depths on either side of the Belle Fourche-Cheyenne River drainage divide were scanned to determine which way water in the pre drainage divide drainage system had flowed. Based on the longer length of Cheyenne River tributaries and the deeper depth of the Cheyenne River valley the pre drainage divide drainage system flow direction was interpreted to have been in a southeast direction. Cheyenne River tributaries were observed to usually flow from the drainage divide in southeast directions while Belle Fourche River tributaries were observed to often flow from the divide in northwest directions suggesting headward erosion of the northeast-oriented Belle Fourche 
River valley beheaded and reversed southeast-oriented flow channels. Opposing valleys linking closely spaced valley remnants were studied in both directions to determine if they converged in what are now opposing downstream directions. Such convergence was interpreted to mean that prior to Belle Fourche River valley headward erosion diverging and converging channels had eroded the closely spaced valley remnants. Evidence for such diverging and converging channels was found along all studied drainage divide segments and was interpreted to mean a large anastomosing channel complex had once crossed the entire drainage divide area. Valley remnant depths were determined by comparing drainage divide elevations on valley remnant floors with drainage divide elevations at nearby high points. Depths of the total erosion accomplished as the southeast-oriented water flowed across the eastern Powder River Basin were determined from present day elevations at Pumpkin Buttes and elevations along the Pine Ridge Escarpment and Hay Creek Breaks rims.

\section{Results}

\subsection{South Prong Belle Fourche River-Bates Creek Drainage Divide Segment}

The South Prong Belle Fourche River-Bates Creek drainage divide area seen in figure 2 is located at the Belle Fourche River-Cheyenne River drainage divide southwest end. To the north and east of figure 2 the South Prong joins southeast-oriented Belle Fourche River headwaters to form the northeast-oriented Belle Fourche River. To the west of the South Prong and of the Belle Fourche River headwaters (north of figure 2) is the Cottonwood Creek drainage basin with Cottonwood Creek flowing in a northwest direction to join the north-oriented Powder River. A triple drainage divide where the Belle Fourche River, Cheyenne River, and Powder River drainage basins meet is just to the south of the South Prong headwaters. To the southwest of that triple drainage divide the northwest-oriented Cottonwood Creek headwaters are linked by a valley remnant (number 1 on figure 2) with a south-southeast oriented Antelope Creek tributary, with Antelope Creek flowing to the Cheyenne River. The valley remnant has a floor elevation of 5388 feet (1642 meters) and drainage divide elevations on either side rise to 5467 feet (1666 meters). A short distance to the northeast another valley remnant (number 2) with the same floor elevation links the northwest-oriented Cottonwood Creek valley with the southeast-oriented Bates Creek headwaters valley with Bates Creek also flowing to Antelope Creek and the Cheyenne River.

Less than 7 miles (11 kilometers) to the north-northwest of the triple divide is the southernmost butte at Pumpkin Buttes, which rises to almost 6000 feet (1829 meters) or more than 500 feet (152 meters) higher than the triple drainage divide elevation. The Cheyenne River flows in a northeast-oriented valley at an elevation of approximately 4000 feet (1219 meters) approximately 30 miles (48 kilometers) to the southeast and after another 65 miles (105 kilometers) elevations along the Hat Creek Breaks rim rise to more than 5100 feet (1555 meters). These elevations suggest more than 1000 feet (305 meters) of sedimentary bedrock has been removed from much of the intervening the Cheyenne River drainage basin. Immense volumes of water were needed to accomplish that erosion and the water had to come from somewhere and also move in ways that created present day drainage routes and drainage divides. Established paradigm rules provide researchers seeking to determine how the Cheyenne River drainage basin was excavated and how the triple drainage divide originated with explanatory mechanisms such as normal erosion processes, climatic change, and long periods of time. Using such mechanisms geomorphologists can at best construct vague and generalized erosion histories. The new paradigm rules provide researchers with the mechanism of massive southeast-oriented floods and remaining discussions in this results section demonstrate how massive southeast-oriented floods eroded the illustrated and described erosional landforms.

Water flowing in diverging and converging channels across the present day north-oriented Powder River drainage basin to the Cheyenne River valley eroded valleys now preserved at the figure 2 locations 1 and 2 . Large southeast-oriented floods flowing across the region would have flowed in diverging and converging channels and would have eroded southeast-oriented tributary valleys headward from the northeast-oriented Cheyenne River valley. Headward erosion of the deep north-oriented Powder River valley would have beheaded and reversed flow in those southeast-oriented channels so as to create drainage divides and northwest-oriented Powder River tributaries. To the east of the triple drainage divide shallower valley remnants (numbers 3, 4, 5, 6, and 7) link the east and north-northeast oriented South Prong valley with southeast-oriented Bates Creek headwaters valleys. One or two 20 -foot (6-meter) contour lines define these valley remnants, which were eroded by south-oriented streams of water that converged in the southeast-oriented Bates Creek valley. What must have happened is the east-oriented South Prong headwaters valley eroded headward across the diverging and converging channels, but was unable to capture water moving in the channels where valley remnants numbered 1 and 2 are now located. North-oriented South Prong valley segments (north of valley remnants numbered 6 and 7) probably were formed by reversals of flow on north ends of beheaded south-oriented flow channels. Interestingly relative ages of the three drainage basins can be determined from the figure 2 evidence. Headward erosion of the 
northeast-oriented Belle Fourche River valley first captured southeast-oriented flow moving to the Cheyenne River valley and headward erosion of the north-oriented Powder River valley next beheaded and reversed southeast-oriented flow moving to the newly eroded Belle Fourche River valley and to the Cheyenne River valley.

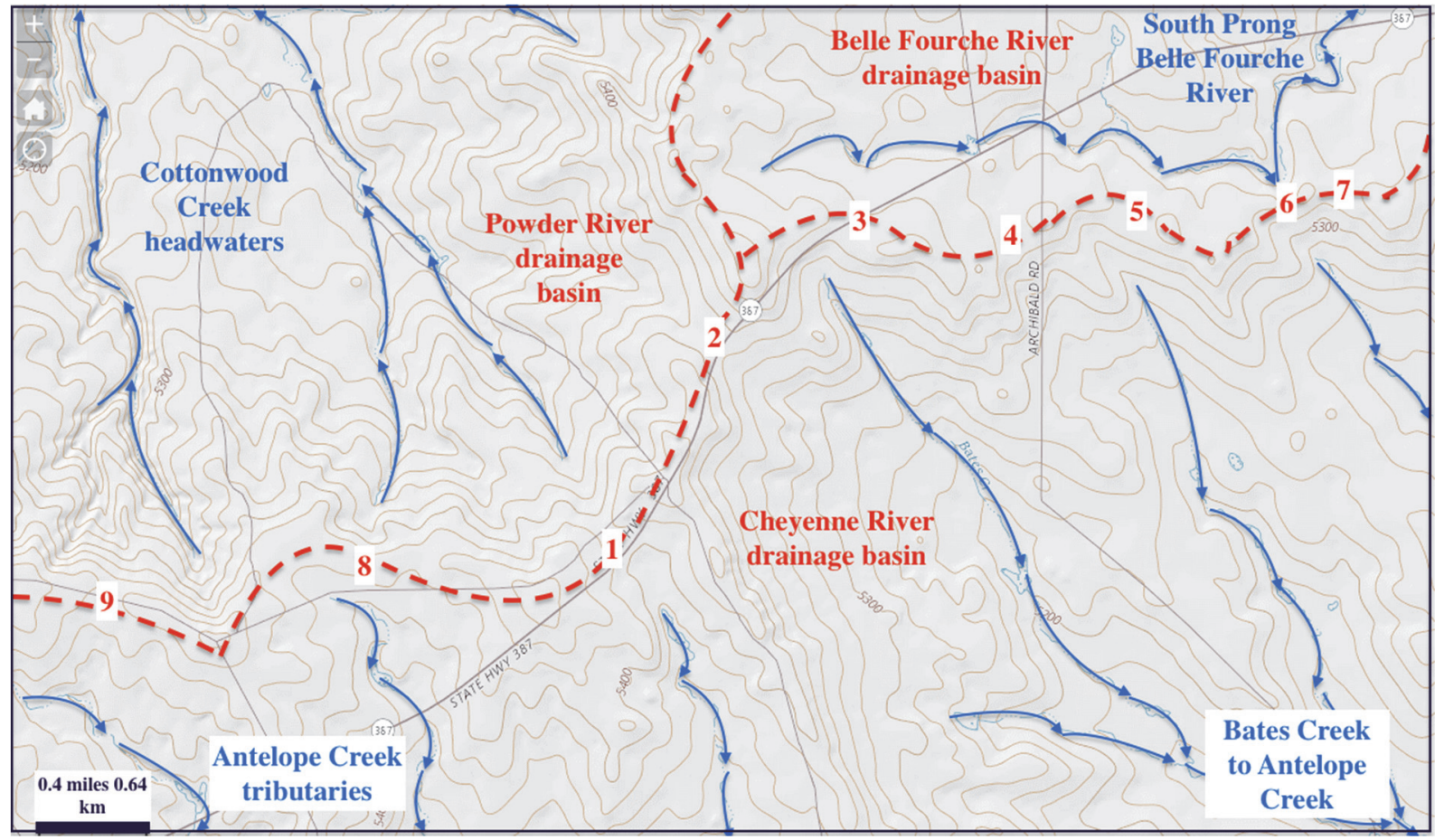

Figure 2. Modified map from USGS National Map website showing Belle Fourche River-Cheyenne River drainage divide southwest end (the contour interval is 20 feet or 6 meters). Blue arrows show present day drainage routes and flow directions. Dashed red lines show major drainage divides and red numbers identify locations discussed in the text

\subsection{Belle Fourche River-Porcupine Creek Drainage Divide Segment}

Figure 3 shows a Belle Fourche River-Porcupine Creek drainage divide segment to the east of a north-oriented Belle Fourche River segment and to the northeast of figure 2. Between figures 2 and 3 additional valley remnants cross the Belle Fourche-Cheyenne River divide and some link short northwest-oriented Belle Fourche River tributaries with southeast-oriented Bates Creek tributaries. Other valley remnants link short northwest-oriented Belle Fourche River tributaries with southeast-oriented Spring Creek headwaters. Spring Creek, like Bates Creek, is a southeast-oriented Antelope Creek tributary. The northwest-oriented drainage system seen in figure 3 drains to the nearby north-oriented Belle Fourche River while southeast-oriented drainage flows to southeast-oriented Porcupine Creek and then to Antelope Creek before reaching the Cheyenne River. Locations identified by numbers 1,2 , and 3 (in figure 3) are valley remnants crossing the drainage divide and are residuals of valleys that once crossed the region. Differences between the valley remnant floor elevations and drainage divide high points suggest channels that once crossed this drainage divide segment were more than 75 feet (23 meters) deep.

The Belle Fourche River-Cheyenne River divide is asymmetric with the distance in figure 3 to the Belle Fourche River being about 3 miles (5 kilometers) and to the Cheyenne River being approximately 30 miles (48 kilometers). The northwest-oriented stream seen in figure 3 joins the Belle Fourche River at an elevation of approximately 4950 feet (1509 meters) or more than 300 feet ( 91 meters) below figure 3 high points. Headward erosion of a 300-foot (91-meter) deep Belle Fourche River valley must have beheaded and reversed southeast-oriented flood flow channels moving water across the region to not only create the Belle Fourche-Cheyenne River drainage divide, but also to create the northwest-oriented Belle Fourche River tributary seen in figure 3. Southeast-oriented flood flow moving across the region had eroded the southeast-oriented Porcupine Creek headwaters valley seen in figure 3 prior to the Belle Fourche River-Cheyenne River drainage divide creation. 


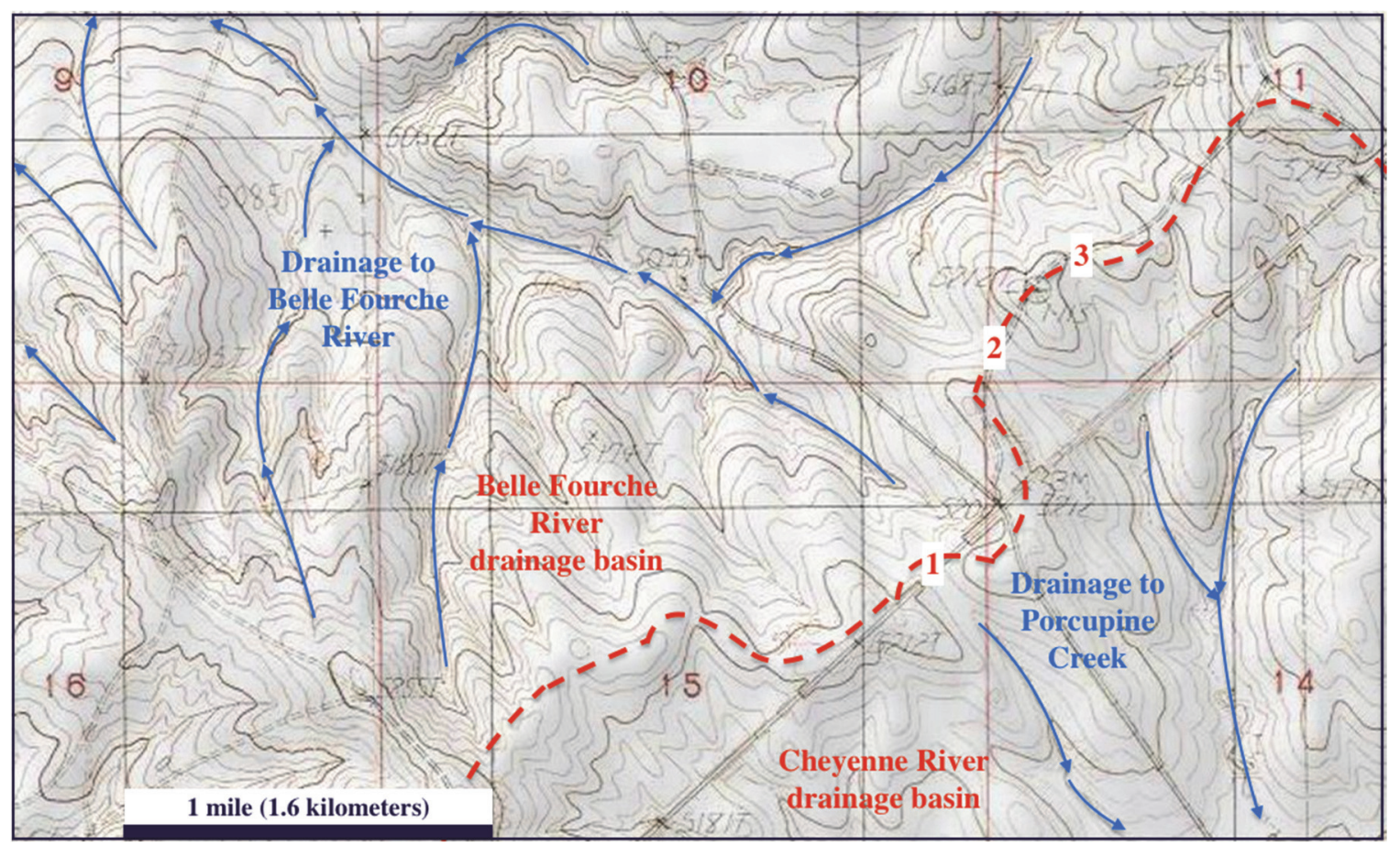

Figure 3. Modified topographic map from the USGS National Map website showing a section of the Belle Fourche River-Porcupine Creek drainage divide (shown by dashed red line). The red numbers identify locations discussed in the text. The contour interval is 10 feet ( 3 meters)

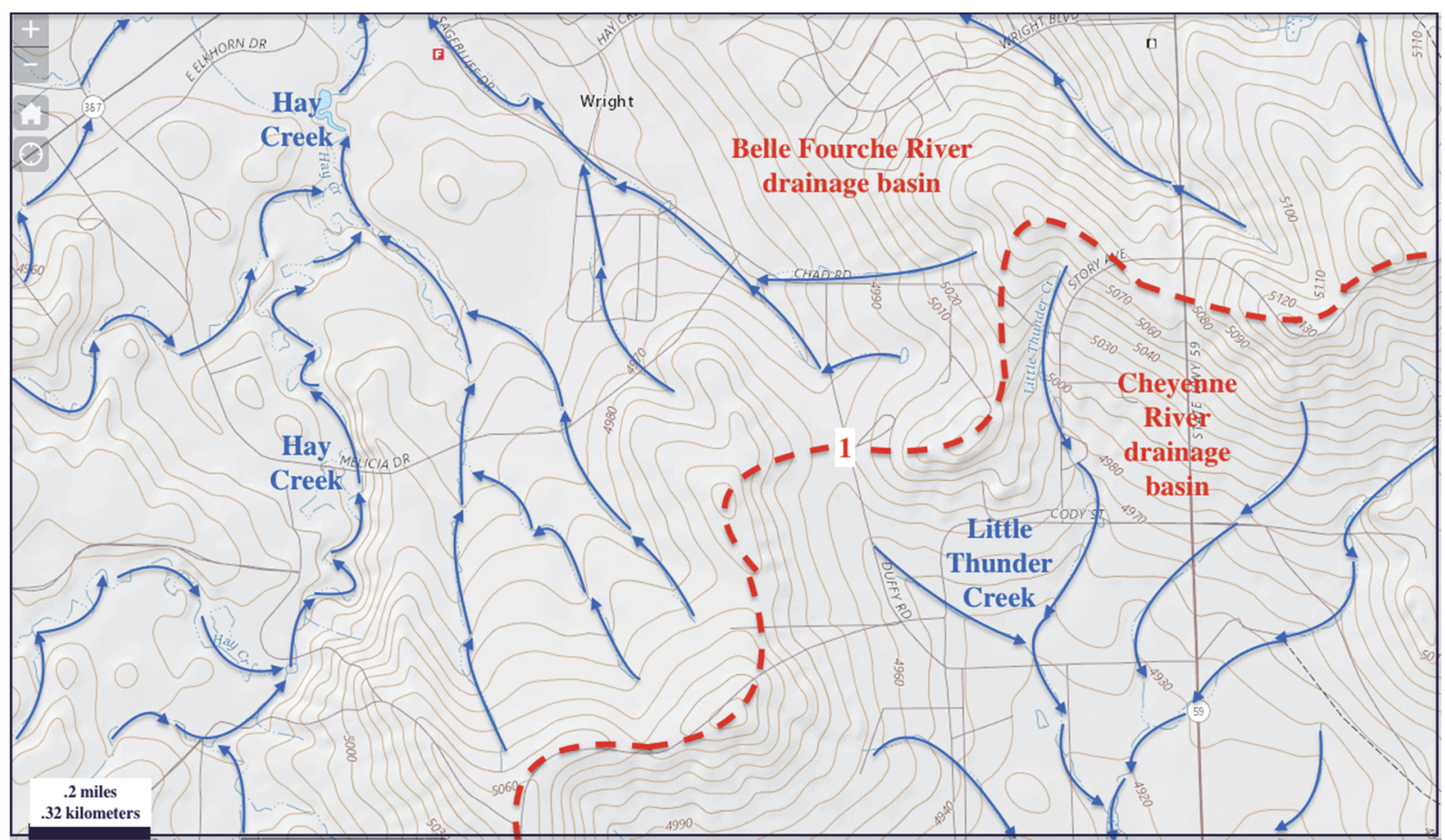

Figure 4. Modified topographic map from USGS National Map website showing a segment of the Hay

Creek-Little Thunder Creek drainage divide. Blue arrows show drainage routes and directions and the dashed red line follows the drainage divide. The contour interval is 10 feet ( 3 meters) and the red number identifies a location discussed in the text 
Southeast-oriented Little Thunder Creek headwaters (seen in figure 4) flow to southeast-oriented Black Thunder Creek and then to the Cheyenne River and are linked by a through valley (number 1 in figure 4) with a northwest-oriented tributary to north-northeast oriented Hay Creek, which flows to the northeast-oriented Belle Fourche River. The floor elevation at number 1 is 4976 feet (1517 meters) and drainage divide elevations on either side rise to more than 5110 feet (1558 meters) suggesting the valley was at least 130 feet (40 meters) deep. Water flowing in a southeast direction from the Hay Creek valley to the Little Thunder Creek valley eroded the valley before headward erosion of the north-northeast oriented Hay Creek valley beheaded and reversed the south-oriented oriented flow to create the northwest-oriented Hay Creek tributary route and the Hay Creek-Little Thunder Creek drainage divide. Not seen in figures 3 and 4 are valley remnants linking northeast-oriented Hay Creek headwaters (south and west of figure 4) with south-oriented Porcupine Creek headwaters. Also not seen and to the northeast of figure 4 are several valley remnants, one of which is more than 100 feet (30 meters) deep, now crossing the Belle Fourche-Cheyenne River drainage divide and linking south-oriented North Prong Little Thunder Creek headwaters with northwest-oriented Hay Creek tributaries. These and other valley remnants suggest a complex of diverging and converging streams flowed across the entire region and were systematically beheaded and reversed by headward erosion of the deeper Belle Fourche River valley and its Hay Creek tributary valley.

\subsection{Coal Creek-Black Thunder Creek Drainage Divide Segment}

Coal Creek is a north-northwest oriented Belle Fourche River tributary and Black Thunder Creek is a southeast-oriented Cheyenne River tributary. Figure 5 shows the Coal Creek-Black Thunder Creek drainage divide western end and also a segment of Hay Creek-Coal Creek drainage divide where as previously mentioned Hay Creek flows to the Belle Fourche River. Multiple through valleys link northwest-oriented Hay Creek tributary headwaters with the north-oriented West Fork Coal Creek valley. Through valley floor elevations vary from 4820 feet (1469 meters) at location 1a to 4859 feet (1481 meters) at location 1d (where there are multiple through valleys). High points between these valley remnants all exceed 4900 feet (1494 meters) and some exceed 4950 feet (1509 meters). All of these valley remnants are oriented in northwest-to-southeast directions. Southeast-oriented diverging and converging channels moving water across what is now the Hay Creek valley into the West Fork Coal Creek valley area eroded these valleys. Initially the southeast-oriented water flowed across the West Fork Coal Creek drainage basin to reach the southeast-oriented Black Thunder Creek valley. Headward erosion of the north-oriented West Fork Coal Creek valley captured the southeast-oriented flow and diverted the water to what must have been an actively eroding northeast-oriented Belle Fourche River valley.

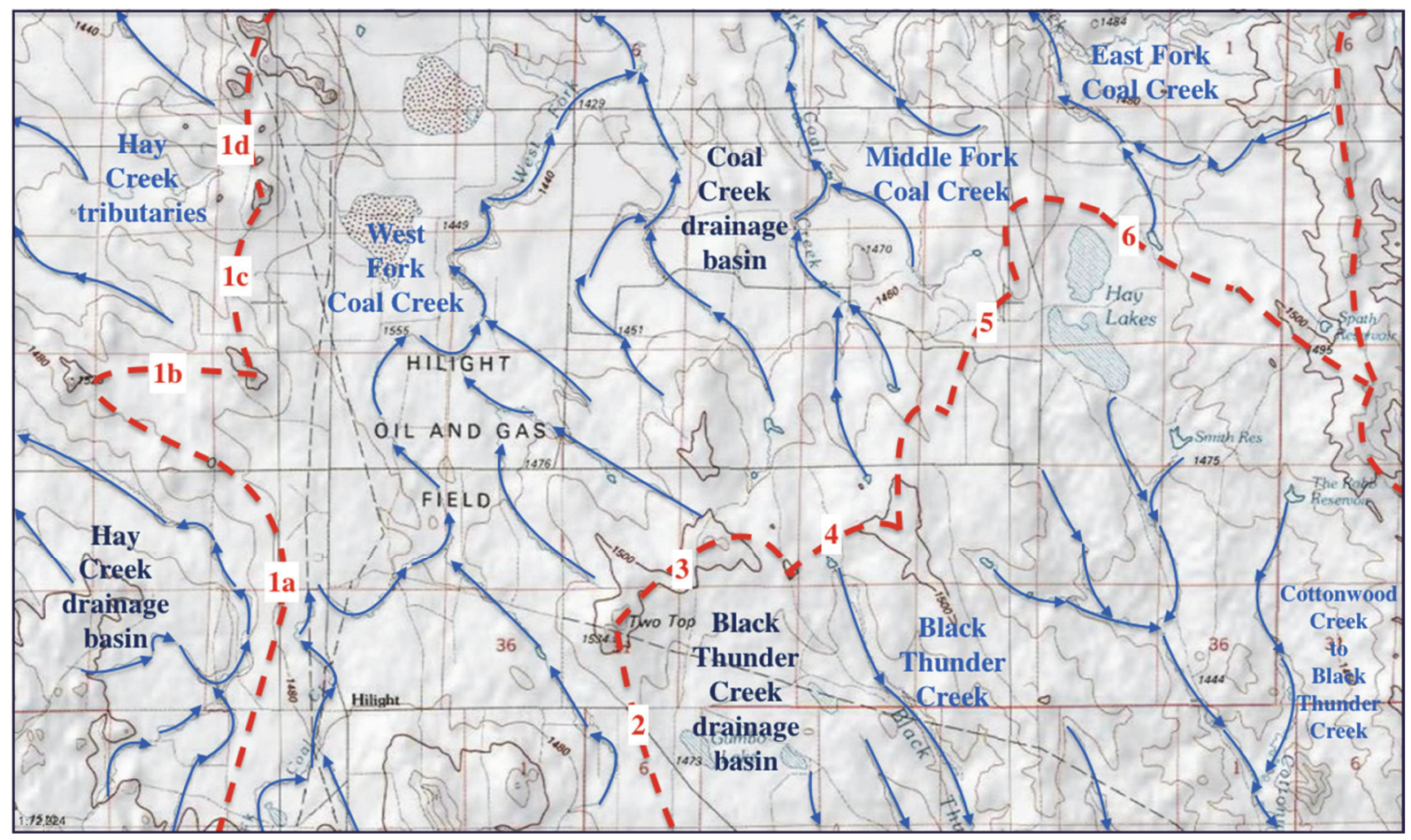

Figure 5. Modified map from USGS National Map website showing a Coal Creek-Black Thunder Creek drainage divide segment. Blue arrows show drainage routes and directions. Dashed red lines show major 
drainage divides and red numbers identify locations discussed in the text. Grid lines are spaced 1 mile (1.6 kilometers) apart. The contour interval is 20 meters (66 feet)

Multiple through valleys, some quite broad, link northwest-oriented West Fork Coal Creek tributaries with the Black Thunder Creek valley (at locations 2, 3 and 4 in figure 5). Two Top is a butte between the through valleys at locations 2 and 3 and rises to 5032 feet (1534 meters) and valley floor elevations at locations 2, 3, and 4 are 200 feet (61 meters) lower. Diverging streams of water flowing from the Hay Creek drainage basin and across the north-oriented West Fork Coal Creek valley and then converging in the Black Thunder Creek valley must have eroded the valleys at locations 2,3 , and 4 . The valley remnant at location 4 was eroded by south-oriented water that flowed along the north-oriented Middle Fork Coal Creek alignment. Through valleys at location 5 and location 6 suggest anastomosing channels of southeast-oriented water flowed along both the Middle and East Fork Coal Creek alignments to reach the southeast-oriented Cottonwood Creek valley, which south of figure 5 joins the Black Thunder Creek valley and that headward erosion of the northeast-oriented Belle Fourche River valley (north of figure 5) systematically beheaded and reversed southeast-oriented channels to create the drainage divide and north-oriented tributaries seen today.

\subsection{Four Horse Creek-Lodgepole Creek Drainage Divide Segment}

Four Horse Creek is a north and north-northwest oriented Belle Fourche River tributary and Lodgepole Creek is a southeast-oriented Cheyenne River tributary. Location 1 on the Four Horse Creek-Lodgepole Creek drainage divide segment seen in figure 6 identifies what appears to be a broad northwest-to-southeast oriented valley remnant. Drainage divide elevations to the southwest exceed 5100 feet (1554 meters) and to the northeast and north the drainage divide elevations rise to more than 5000 feet (1524 meters). Between those areas are multiple ups and downs and areas with most elevations below 4900 feet (1494 meters) and with some deeper valley remnants having floor elevations as low as 4860 feet (1481 meters). These elevations suggest multiple closely spaced southeast-oriented channels or a broad southeast-oriented river with multiple channels eroded 100-foot (30-meter) deep or deeper valleys into the region. The water flowed from what is today the north-oriented Four Horse Creek drainage basin to the southeast-oriented Lodgepole Creek valley and then to the Cheyenne River. Headward erosion of the north-oriented Four Horse Creek valley across a flood formed complex of southeast-oriented anastomosing channels not only explains the drainage divide formation, but also the northwest-oriented Four Horse Creek tributary orientations.

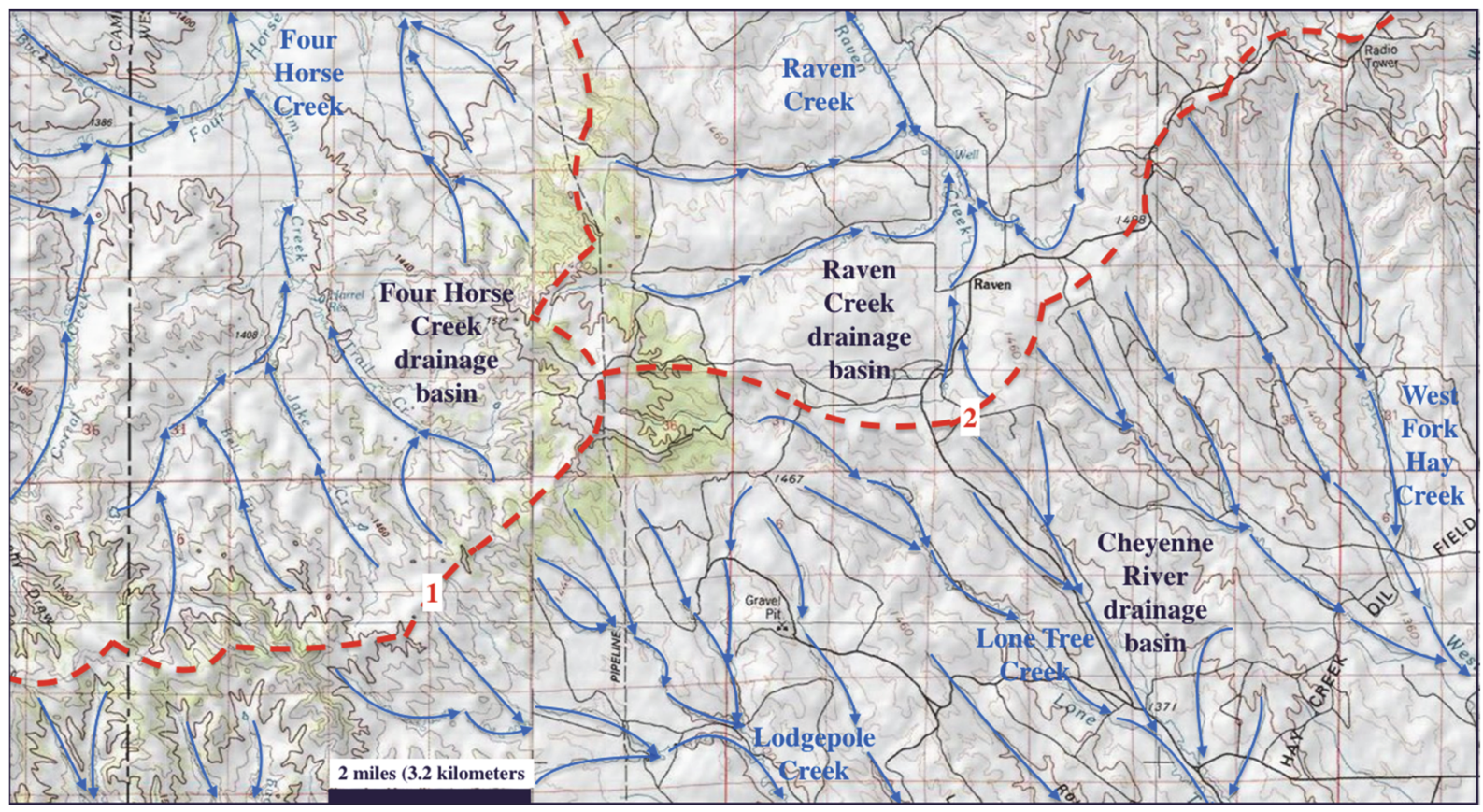

Figure 6. Modified map from USGS National Map website showing the Four Horse Creek-Lodgepole Creek and Raven Creek-Lone Tree Creek drainage divide areas. Blue arrows show drainage routes and directions. Dashed red lines show drainage divides and red numbers identify locations discussed in the text. The contour interval is 20 meters (66 feet) 


\subsection{Raven Creek-Lone Tree Creek Drainage Divide Segment}

Also seen in figure 6 is the Raven Creek-Lone Tree Creek drainage divide. Raven Creek is a northwest-oriented stream flowing to the northeast-oriented Belle Fourche River and Lone Tree Creek is a southeast-oriented stream flowing to southeast-oriented Lodgepole Creek, which flows to the Cheyenne River. High points on either side of the Raven Creek-Lone Tree Creek drainage divide at location 2 (in figure 6) rise to more than 5000 feet (1524 meters). Multiple valley remnants with floor elevations lower than 4800 feet (1463 meters) now cross the drainage divide and suggest water flowed in diverging and converging channels in south and southeast directions from what is today the northwest-oriented Raven Creek drainage basin to the southeast-oriented Lone Tree Creek valley. Headward erosion of the deep northeast-oriented Belle Fourche River valley to the north of figure 6 beheaded and reversed the southeast-oriented water so as to create the northwest-oriented Raven Creek drainage route and the Raven Creek-Lone Tree Creek drainage divide (which is also the Belle Fourche River-Cheyenne River drainage divide).

\subsection{Buffalo Creek-Hay Creek Drainage Divide Segment}

Buffalo Creek is a north-northwest oriented tributary to the northeast-oriented Belle Fourche River and Hay Creek is a south and southeast-oriented tributary to southeast-oriented Lodgepole Creek, which flows to the Cheyenne River. Figure 7 shows the Buffalo-Hay Creek drainage divide western half. The asymmetric drainage divide has steeper slopes leading into the Hay Creek (Cheyenne River) drainage basin, which suggests the Hay Creek drainage basin was eroded headward as a large headcut by large volumes of south-oriented water that must have flowed across the present day north-oriented Buffalo Creek drainage basin. Valley remnants or low points on the drainage divide identify former valley locations. The drainage divide to the southeast of location 3 rises to more than 5040 feet (1536 meters) and to the west of location 2 to more than 5060 feet (1542 meters) suggesting the intervening area was deeply eroded with valley remnants at locations 1,2 , and 3 documenting regional erosion of more than 100 feet (30 meters). Location 4 is shown because elevations are decreasing as the Buffalo Creek drainage divide with south-oriented East Fork Hay Creek is reached. Several valley remnants cross that drainage divide (not shown in figures here) and have floor elevations of less than 4880 feet (1487 meters). Those valley remnants probably originated as diverging and converging south- and southeast-oriented flood flow channels.

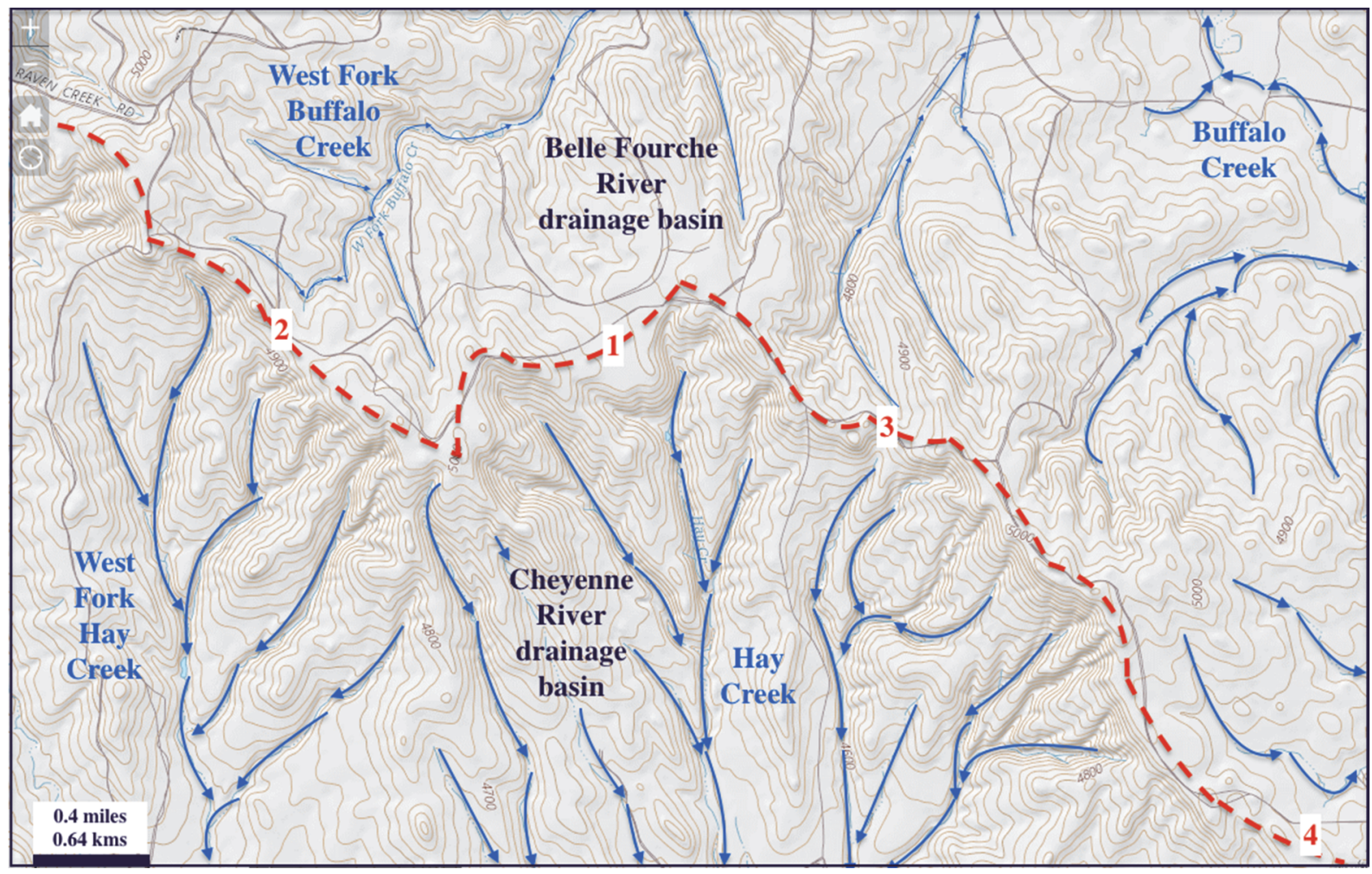

Figure 7. Modified map from USGS National Map website showing a section of the Buffalo-Hay Creek drainage divide. Blue arrows show drainage routes and directions. The red dashed line follows the drainage divide and red numbers refer to locations discussed in the text. The contour interval is 20 feet (6 meters) 


\subsection{Wind Creek-Beaver Creek Drainage Divide Segment}

Wind Creek is a predominantly north-northwest oriented Belle Fourche River tributary with north- and northeast-oriented headwaters and tributaries. Beaver Creek is a southeast-oriented Cheyenne River tributary and for much of its route flows on the easily eroded Pierre Shale outcrop. Figure 8 shows a segment of the Wind Creek-Beaver Creek drainage divide. Location 1 identifies the drainage divide between the southeast-oriented Beaver Creek headwaters and a short northwest-oriented Wind Creek tributary and location 2 identifies the drainage divide between a southeast-oriented Beaver Creek tributary and the north-oriented Wind Creek valley. The elevation at location 1 is 4445 feet (1355 meters) and the elevation at location 2 is 4447 (1355 meters). The high point on the hogback ridge between locations 1 and 2 has an elevation of 4538 feet (1383 meters). Just to the north of figure 8 an even deeper through valley located between two hogback ridges links a northwest-oriented Wind Creek tributary with a southeast- and south-oriented Beaver Creek tributary and the elevation at the drainage divide on that through valley's floor is 4407 feet (1343 meters). Continuing in a northeast direction is another through valley, also between hogback ridges, in which a railroad crosses the drainage divide at an elevation of 4368 feet (1331 meters). Diverging and converging channels formed during a large south- or southeast-oriented flood eroded each of these valley remnants with the drainage divide being created by headward erosion of the Wind Creek valley across those southeast-oriented flood flow channels. Elevations along this drainage divide segment are approximately 900 feet (274 meters) lower than at the triple drainage divide in figure 2. A case could be made that the lower drainage divide elevations seen in figure 8 are related to deeper erosion in the Wind Creek-Beaver Creek drainage divide area than in the South Prong Belle Fourche River-Bates Creek drainage divide area. If so much deeper erosion occurred in the Wind Creek-Beaver Creek drainage divide area than what occurred in the region further to the southwest.

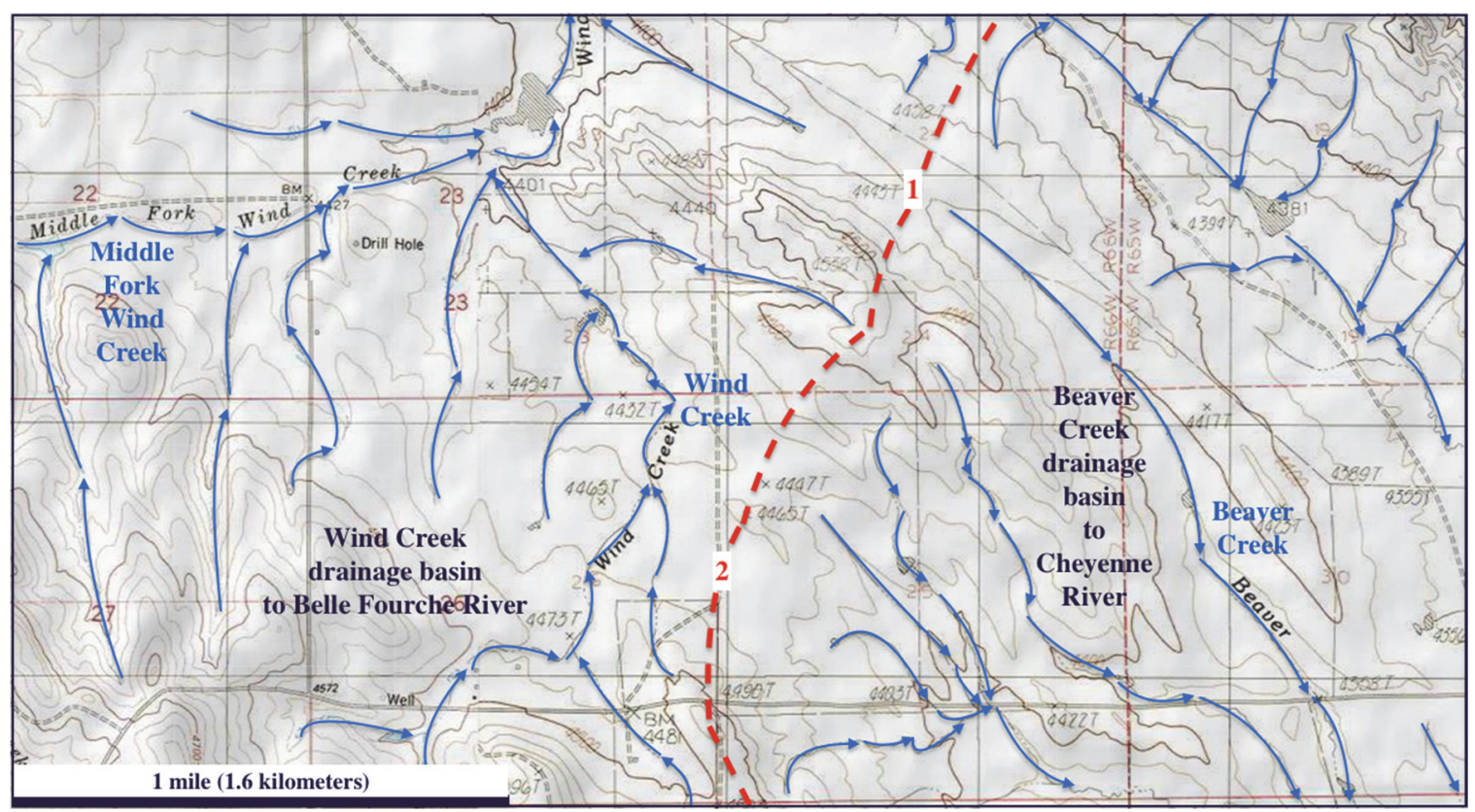

Figure 8. Modified map from USGS National Map website showing a Wind Creek-Beaver Creek drainage divide segment. Blue arrows show drainage routes and directions and the dashed red line shows the drainage divide location. The contour interval is 20 feet (6 meters)

\section{Discussion}

Based on the above topographic map evidence there can be little doubt that many if not all low points found on the Belle Fourche-Cheyenne River drainage divide Powder River Basin segment are former valley remnants and it is not difficult to demonstrate southeast-oriented water moving in diverging and converging channels once flowed in those valleys. In addition, based on the Pumpkin Buttes elevations and high plains elevations above the Pine Ridge Escarpment and Hay Creek Breaks rims, erosion must have removed as much as 500-1000 feet 
(152-304 meters) of sedimentary rock from the Powder River Basin section of the Belle Fourche-Cheyenne River drainage divide area and even more from the present day Cheyenne River drainage basin to the south and southeast. These observations can be made from paradigm neutral topographic maps and are valid no matter what paradigm rules are used. However, the established paradigm's rules make explaining such observations difficult, if not impossible because those rules forbid massive southeast-oriented continental ice sheet melt water floods from reaching the Powder River Basin. A quick look at figure 1 shows such melt water floods would have had to cross what the established paradigm considers to be pre-glacial northeast-oriented rivers flowing down a pre-glacial northeast-oriented regional slope. That slope would have prevented any continental ice sheet melt water from reaching the Powder River Basin. Without a large water source to explain Powder River Basin erosional landform origins geomorphologists abiding by established paradigm rules are left with no choice, but to treat the Powder River Basin erosional landform features as unexplainable anomalous evidence.

The new paradigm's rules make explanations of the above discussed evidence easy by requiring at least one North American continental ice sheet to have modified the North American continent surface in ways that would have permitted large southeast-oriented continental ice sheet melt water floods to flow across the Powder River Basin. However, critics may argue explanations based on the new paradigm's rules do not adequately recognize published age dates. For example, Coates and Heffern (1999), Heffern and Coates (2004) and Riihimaki et al (2009) present numerous age dates obtained from Powder River Basin clinker, a hard red rock formed when underlying coal beds naturally burn. To burn the coal beds must be above the water table, which implies the coal beds must be near the surface and the published age dates suggest Powder River Basin clinker has been forming for at least 4 million years. Riihimaki et al associate the coal fires with climatically controlled landscape evolution, but provide few landscape evolution details. The Riihimaki et al explanations and age dates were obtained by following the established paradigm's rules and are fundamentally different from explanations obtained by following the new paradigm's rules. The two paradigms are fundamentally different and one paradigm cannot be judged by the other paradigm's rules. Each paradigm's productivity or ability to explain observed evidence is what is important.

Interestingly, evidence described here when interpreted by new paradigm rules and combined with evidence presented in previously cited Clausen papers $(2017 \mathrm{a}, 2017 \mathrm{~b}, 2017 \mathrm{c}, 2018)$ can be used to develop a preliminary Pine Ridge Escarpment origin explanation. That explanation begins by assuming large southeast-oriented floods initially flowed on a surface as high or higher than the present day Pumpkin Buttes tops (in the Powder River Basin), the Pine Ridge Escarpment and Hay Creek Breaks rims (along the Powder River Basin south margin), and the top of what was then an emerging Black Hills upland. The explanation also assumes a continental ice sheet extended across all of eastern South Dakota, the continental ice sheet floor was lower in elevation than where southeast-oriented ice-marginal melt water floods were flowing and a south-oriented supra-glacial melt water river had sliced a deep ice-walled and bedrock-floored canyon into the ice sheet surface along a route now identified by the east-facing Missouri Escarpment and the west-facing Prairie Coteau Escarpment. Immense volumes of melt water emerging from that ice-walled canyon's mouth under those conditions would have eroded the deep Missouri River valley headward to reach what is now the Yankton, South Dakota area and a deep east-oriented valley could have eroded headward from that deep Missouri River valley roughly following what is today the White River alignment and the Pine Ridge Escarpment base. Massive southeast-oriented floods moving into that east-oriented valley from the northwest would have removed all evidence of that valley's north wall and the high-level surface that once extended across western South Dakota. Many details need to be filled in, but this preliminary explanation illustrates how the new paradigm rules permit an explanation of another previously unexplained and regionally significant erosional landform.

\section{Conclusions}

Paradigms are frameworks of rules or assumptions governing how a research discipline investigates evidence. By themselves paradigms are neither correct nor incorrect and are ultimately judged by their productivity, or ability to explain evidence and to lead researchers to new research problems. Of the two paradigms compared here the established paradigm forbids large continental ice sheet melt water floods from reaching the northeast Wyoming Powder River Basin. As a result investigators abiding by established paradigm rules must treat many, if not all, Powder River Basin erosional landforms as unexplained anomalous evidence. Yet by following the new paradigm's rules the study of detailed topographic map evidence presented here permitted most, if not all of those erosional landforms to be easily explained. Combined with western South Dakota and southwest North Dakota erosional landforms explained in other published papers (e.g. Clausen 2017a, 2017b, 2017c, 2018) the new paradigm's rules have successfully demonstrated their ability to explain many regional landscape features. The success of this and other similar new paradigm demonstrations suggest that by following the new 
paradigm's rules regional geomorphologists can determine most if not all specific erosional landform origins.

\section{Acknowledgements}

Columbia University courses taught by Arthur Strahler during 1964-5 enhanced the author's map interpretation skills and made him aware of the regional geomorphology research community's inability to explain erosional landform origins. Brainerd Mears and other University of Wyoming Geology Department faculty members during the late 1960s introduced the author to many unsolved Rocky Mountain and Great Plains region erosional landform origin problems. Preliminary work leading to this paper was done while employed at Minot State University (North Dakota) where other faculty members and library staff greatly assisted in developing and then providing access to needed topographic map collections.

\section{References}

Alden, W. C. (1932). Physiography and glacial geology of eastern Montana and adjacent areas. U. S. Geol. Survey Prof. Paper, 174, 133.

Baker, V. R. ed. (1981). Catastrophic flooding; the origin of the channeled scabland. Dowden, Hutchinson and Ross, Inc. Stroudsburg, PA p. 276-310.

Bretz, J. H. (1927). Channeled Scabland and the Spokane Flood. Washington Academy of Science Journal, 17, 200-211.

Clausen, E. (2017a). Solving a perplexing Scenic and Sage Creek drainage history problem, Pennington, County, South Dakota, USA. Journal of Geography and Geology, 9(2), 1-10. https://doi.org/10.5539/jgg.v9n2p1

Clausen, E. (2017b). Origin of Little Missouri River-South Fork Grand River and nearby drainage divides in Harding County, South Dakota and adjacent eastern Montana, USA. Open Journal of Geology, 7, 1063-1077. https://doi.org/10.4236/ojg.2017.78071

Clausen, E. (2017c). Using map interpretation techniques for relative dating to determine a western North Dakota and South Dakota drainage basin formation sequence, Missouri River drainage basin, USA. Journal of Geography and Geology, 9(4), 1-18. https://doi.org/10.5539/jgg.v9n4p1

Clausen, E. (2018). Topographic map analysis of high elevation Black Hills through valleys linking Spearfish and Rapid Creek headwaters valleys, Lawrence County, South Dakota, USA. Journal of Geography and Geology, 10(1), 8-21. https://doi.org/10.5539/jgg.v10n1p8

Coates, D. A., \& Heffern, E. L. (1999). Origin and geomorphology of clinker in the Powder River Basin, Wyoming and Montana, in Miller, W.R. ed. Coalbed methane and the Tertiary geology of the Powder River Basin Wyoming and Montana: Wyoming Geological Association 50th Annual Field Conference Guidebook, 211-230.

Darton, N. H. (1909). Geology and water resources of the northern portion of the Black Hills. U.S. Geological Survey Professional Paper, 65, 77-78.

Fenneman, N. M. (1931). Physiography of the western United States: McGraw-Hill Book Company Inc., New York, p. 18.

Flint, R. F. (1938). Origin of the Cheney-Palouse scabland tract, Washington. Geological Society of America Bulletin, 49, 461-523. https://doi.org/10.1130/GSAB-49-461

Flint, R. F. (1949). Pleistocene drainage diversions in South Dakota. Geografisker Annaler, 31, 56-74. https://doi.org/10.2307/520352

Flint, R. F. (1955). Pleistocene geology of eastern South Dakota: United States Geological Survey Professional Paper 262, $174 \mathrm{p}$.

Gravenor, C. P. (1975). Erosion by continental ice sheets: American. Journal of Science, 275, 594-604. https://doi.org/10.2475/ajs.275.5.594

Gregory, R. W., \& Michale, D. C. (2007). Geologic map of the Bill 30' x 60' quadrangle: Wyoming State Geological Survey Map Series MS-72.

Heffern, E.L., and Coates, D. A. (2004). Geologic history of natural coal-bed fires, Powder River basin, USA. International Journal of Coal Geology, 50(1-2), 25-47. https://doi.org/10.1016/j.coal.2003.07.002

Higgs, R. (1978). Provenance of Mesozoic and Cenozoic sediments from the Labrador and west Greenland 
continental margins: Canadian Journal of Earth Sciences 15, 1850-1860. https://doi.org/10.1139/e78-192

Karlstrom, K. E., Less, J. P., Kelley, S. A., \& Crow, R. S., et al. (2014). Formation of the Grand Canyon 5 to 6 million years ago through integration of older paleocanyons. Nature Geoscience, 7(3), 239-244. https://doi.org/10.1038/NGEO2065

Kehew, W. E. (1982). Catastrophic flood hypothesis for the origin of the Souris spillway, Saskatchewan and North Dakota. Geological Society of America Bulletin, 93, 1051-1058. https://doi.org/10.1130/0016-7606(1982)93<1051:CFHFTO >2.0.CO;2

Kuhn, T. S. (1962). The Structure of Scientific Revolutions (second edition, enlarged), The University of Chicago Press, 210 pages.

Love, J. D. (1960). Cenozoic sedimentation and crustal movement in Wyoming. American Journal of Science, 258-A, 204-214.

Mclaughlin, J. F., \& Ver Ploeg, A. J. (2006). Geologic map of the Newcastle 30" x 60' Quadrangle: Wyoming State Geological Survey Map Series MS-71.

Meyerhoff, H. A., \& Olmstead, E. W. (1937). Cenozoic leveling in the Black Hills (abstract): Pan-Am Geologist, $68,306$.

Riihimaki, C. A., Reiners, P. W., \& Heffern, E. L. (2009). Climate control on Quaternary coal fires and landscape evolution, Powder River basin, Wyoming and Montana. Geology, 37(3), 255-258. https://doi.org/10.1130/G25195A.1

Rutter, N. W. (1980). Erosion by Pleistocene continental ice sheets in the area of the Canadian Shield (INFO--0014): Report prepared for the Atomic Energy Board, Ottawa. Canada.

Sears, J. W. (2013). Late Oligocene-early Miocene Grand Canyon: A Canadian connection? GSA Today, 23(11), 4-10. https://doi.org/10.1130/GSATG178A.1

Seeland, D. (1985). Oligocene Paleogeography of the Northern Great Plains and Adjacent Mountains: in Flores, R.M. editor, Cenozoic Paleogeography of the West-Central United States. Rocky Mountain Paleogeography Symposium, 3, 187-205.

Stamm, J. F., Hendricks, R. R., Sawyer, J. F., Mahan, S. A., Zaprowski, B. J., Geibel, N. M., \& Azzolimi, D. C. (2013). Late Quaternary stream piracy and strath terrace formation along the Belle Fourche and lower Cheyenne Rivers, South Dakota and Wyoming: Geomorphology, 197, 10-20. https://doi.org/10.1016/j.geomorph.2013.03.028

Strahler, A. N. (1945). Hypotheses of stream development in the folded Appalachians. Geological Society of America Bulletin, 56(1) 45-88. https://doi.org/10.1130/0016-7606(1945)56[45:HOSDIT]2.0.CO;2

Sugden, D. E. (1976). A case against deep erosion of shields by continental ice sheets. Geology, 4, 580-582. https://doi.org/10.1130/0091-7613(1976)4<580:ACADEO >2.0.CO;2

Thornbury, W. D. (1965). Regional geomorphology of the United States: John Wiley and Sons, New York, p. 291.

Todd, J. E. (1902). The hydrographic history of South Dakota. Geological Society of America Bulletin, 13, 27-40. https://doi.org/10.1130/GSAB-13-27

Todd, J. E. (1914). The Pleistocene history of the Missouri River: Science, 39, 263-274. https://doi.org/10.1126/science.39.999.263

United States Geological Survey (USGS) National Map. Retrieved from https://viewer.nationalmap.gov/advanced-viewer/

United States Geological Survey Topoview website. Retrieved from https://ngmdb.usgs.gov/topoview/

Ver Ploeg, A. J., \& Boyd, C. S. (2007). Geologic map of the Reno Junction 30' x 60' quadrangle: Wyoming State Geological Survey Map Series MS-62.

Wanless, H. R. (1923). The stratigraphy of the White River beds of South Dakota. Proceedings of the American Philosophical Society, 62, 190-269.

White, W. A. (1972). Deep erosion by continental ice sheets. Geological Society of America Bulletin, 81(4), 1037-1056. https://doi.org/10.1130/0016-7606(1972)83[1037:DEBCIS]2.0.CO;2

White, W. A. (1988). More on deep glacial erosion by continental ice sheets and their tongues of distributary ice. 
Quaternary Research, 30(2), 137-150. https://doi.org/10.1016/0033-5894(88)90019-1

Zaprowski, B. J., Evenson, E. B., Pazzaglia, F. J., \& Epstein, J. B. (2001). Knickzone propagation in the Black Hills and northern High Plains: a different perspective on the late Cenozoic exhumation of the Laramide Rocky Mountains. Geology, 29 , $547-550$. https://doi.org/10.1130/0091-7613(2001)029<0547:KPITBH>2.0.CO;2

\section{Copyrights}

Copyright for this article is retained by the author(s), with first publication rights granted to the journal.

This is an open-access article distributed under the terms and conditions of the Creative Commons Attribution license (http://creativecommons.org/licenses/by/4.0/). 